\title{
Review
}

\section{A Review of Advantages, Disadvantages and Challenges of Crop Rotations}

Mostafa Mohamed Selim

Field Crops Research Department, National Research Centre, Giza, Egypt.

\begin{abstract}
CROP rotation is the most important cropping system can help to minimize the application $C_{\text {of fertilizers and herbicides, thereby decreased food contamination with agrochemical }}$ residue and increase structure of soil microbial communities. Furthermore, among other benefits, additional benefits also can be gained such as high land use efficiency, superior yield stability, well distributing of labor contribution over the growing season by the way which allows for more choice when deciding on change one practice or more, larger variety of produce, less dependence on storage, greater market opportunities by making a balance in the crop production. Recently, many researches showed that crop rotation is a foundational component of sustainability and long-term profitability without any requirements to additional financial investments. Finally, crop rotation can be recommended in many regions as valuable practices for refining sustainability and long term profitability.
\end{abstract}

Keywords: Sequential-cropping, Mono-cropping, Crop rotation, Crop sequences.

\section{Summary}

This review compiled the global research from the past few years on one of the most important agronomic practices, which is crop sequence (crop rotation). Rotations have a great potential in maximize crop yield production of unit area without any requirements to increase financial investments (Stanger et al., 2008 and Sexton, 2016). Rotation is the most important and effective plans in managing equipment, labor availability, market variability and climate changes. Over time, crop rotations could occurred some benefits, for example increasing level of soil organic matter, thereby enhancing soil quality, reduce soil degradation and rapid going to depletion and advance soil physiochemical composition.

Generally, while rotations are a foundational element of sustainability and long-term profitability, in the same time adopting crop rotation is a complex practice, it is must be adaptable to local conditions and challenges. Also, considerable attention must be looked at natural systems as a model to mimic always needs to improve. Although a corn-soybean rotation is well known and the widespread rotation in many areas, but it is not continuously the dominantor the optimum option. A good rotation program should be productive, minimize nutrient loss, cover the soil, provide resilience against natural constrains, and each crop should offer some benefits to the following crop.

Crop rotation could also help to minimize the application of fertilizers and herbicides,thereby decreased food contamination with agrochemical residue and increase structure of soil microbial communities. Additional benefits also can be gained such as high land use efficiency, superior yield stability, well distributing of labor contribution over the growing season by the way which allows for more choice when deciding on change one practice or more, larger variety of produce, less dependence on storage, greater market opportunities by making a balance in the crop production and well soil and water uses (Edwards, 1995). Additionally, allelopathy effect which is defined by the annihilation of plant growth of specific plant species by another species. Auto toxicity is one of allelopathic categories that happen when chemical components released from a crop root, disturb the same crop species and may be extended to other plant species.

Crop rotation is not new technique, earlier, introduction of the "Norfolk Rotation" (BarleyClover/ryegrass-Wheat-Turnips) by Sir Charles Townshend in England played a large role in nearly tripling England's agriculture output in the 
1700 s in a sustainable manner. This technology also has introduced a lot of improvement provided food and also provides required employment for England's Industrial Revolution.

Recently, many researches, showed that crop rotation is a foundational component of sustainability and long-term profitability without any requirements to additional financial investments (Stanger et al., 2008 and Sexton, 2016). Furthermore, obvious effects of crop rotation were also discovered on soil mineral status, and $(\mathrm{N})$ mineralization (Carpenter-Boggs et al., 2000); increase the efficiency of nutrients use (Tanaka et al., 2005); mitigating the effects of limited nutrient availability (Brozyna et al., 2013); asset in building soil organic matter due to large amount of crop residue; which was left in the soil after harvest (Adiku et al., 2009 and Sexton et al., 2012, 2014); the impact on the structure of microbial communities which are highly respond to host plant; soil characteristics and climatic conditions (Garbeva et al., 2004; Berg \& Smalla, 2009; Lehman et al., 2015 and Benitez et al., 2017) and protecting the soil against erosion, deciding whether, sowing crop in a rotation or as a monoculture is partially depended on many variables such as commodity markets, disease and insect pest's present and available labour and equipment's in the time of crop seeding or crop harvesting.

\section{Introduction}

Among others agronomic practices crop rotations (Crop sequences), are valuable practices can be recommended in many regions for refining sustainability and long term profitability. Crop rotation is an idea of growing different types of crops in a series or as successive seasons, rotating may vary from 2 or 3 years or extended to long time. Dependence on the fact that, different crops are differed in their requirements, whereas crop rotation is contains legumes and non-leguminous plants, thus this is a good idea for improving soil productivity because you can sure that you do not over use soil health and make it more efficiently utilized and enabling to be preserved. Occasionally, crop rotation is may be the better choiceor the dominant option must be followed for maintain production systems. There are several benefits can be gained by using crop rotation, including improved nutrient cycling, soil tilth, and soil physical properties; enhanced weed control, and resulting higher yield, as compared to following a monoculture under identical conditions.

Research on the influence of long-term crop rotation, not only confirmed that, the crop rotations is a best way for managing crop residue, but also is the master key of sustainability and profitability, it is can proved some advantages, which can be subjected in the following topics:

- Crop sequence can help maximize crop yield production of the unit area without any requirements to increase financial investments.

- Crop rotation is an important technique in elimination insects, more breaks in disease cycles and fewer herbicide-resistant weed species. Food and Agriculture Organization (FAO, 2002), recognizes crop rotation as one of the most important methods of integrated pest management (IPM). It is an ecofriendly method of crop production that aims to reduce the use of chemical pesticides and herbicides in agriculture.

- Soil organic matter tended to increase as the result of following crop rotation than monoculture system, then led to better soil structure, reduce soil degradation and rapid going to depletion and advance soil physiochemical composition and soil health.

- Rotating crops is an important practice could mitigate the effect climate changes and market variability.

- Whenever, crop rotation can include forage crops, hence the livestock help to increase the soil nutrients with manure.

Over the last few years, some researchers have also discovered that, although, there are many advantages, also there is some disadvantages, but these are very low as compared to its benefits, for example:

- Sometimes less profitability may be accompanying with the following of crop rotations, when you are forced to reduce the area cultivated with the most profitable crop.

- Sometimes crop flexibility may be decreased, for example selecting a complex crop rotation, 
hence the chance to add alternative cropis decreased.

- Some rotations can have a high initial outlay, involves input of much money to buy different seeds of the different crops species to be sown, alongside more money expended in field preparation. The success, however, for each crop type is not guaranteed and one can end up incurring a loss of harvest.

Indication of the global research on the role of managing agronomic practices in developing and sustainable agricultural production systems, can arguably that the relationship between soils, crops and management practices is a complex relationships. In the light of global water crisis particularly in arid and semiarid regions, especially in the case of planting a water voracious crops, or crops consume much nutrients from the soil during the growing season, this is led to rapid depletion the soil fertility (Higgs et al., 1976; Mannering \& Griffith, 1981; Dick et al., 1986; Peterson \& Varvel, 1989 a and 1989 b; Higgs et al., 1990; Raimbault \& Vyn, 1991; Bullock, 1992; Copeland et al., 1993; Karlen et al., 1994; Varvel, 1994; Riedell et al., 1998; Varvel, 2000; Garbeva et al., 2004; Tanaka et al., 2005; Karlen et al., 2006; Kaye et al., 2007; Bremer et al., 2008; Adiku et al., 2009; Berg \& Smalla, 2009; Seeley, 2012; Brozyna et al., 2013; Sexton et al., 2014; Lehman et al., 2015; Sexton, 2016 and Benitez et al., 2017).

\section{Designing a rotation}

While crop rotation can have many advantages and disadvantages, adopting the most compatible and effective rotation for a specific fieldis linked with number of variables and many factors that must be considered including socio-economic factors that fit with the small holder farming systems; soil preparation which are needed and available equipment's; the current disease and spread insect pests. While rotating a corn-soybean is the most common practice among many farmers in many areas, but it is not always is the best choice. Although it may be rotated Corn-Soybean rotation most traded among many farmers in many areas, may not always be the best choice. Walter et al. (2009), reported that, growing maize in prolonged rotations that include forage legumes may be a more favorable practice than growing maize in monoculture system or 2-yr rotation with soybean.
Thus before decision, need sufficiently addressed to cover the principle aims of crop rotation and also, to avoid counter productive expected, if producers adopt in appropriate technologies. Therefore, attaining the most suitable rotation is complicated, as one management practice may have negative implications on other practices, for example, reducing tillage intensity without use of a sustainable rotation can increase the risk of plant diseases.

\section{Advantages and disadvantages of crop rotations \\ Rotations and plant disease and insect management \\ Rotation is a very valuable and an effective} tool for breaking disease cycles, chiefly when the pathogens have a chance with crop rotation included host crop or invisible in crop residue or soil when you follow no-tillage program or conserving tillage (Beck, 2003 and Pedersen \& Lauer, 2004). The early experiments of Karlen et al. (1994), registered that crop rotations offer the best way to combat weeds, interrupt insect and better control disease cycles. Crop rotation able to reduce the level of inoculum present by introducing resistant varieties or which are not host crops. When planting impervious crop (non-host), the pathogen could not able to complete their cycle life and causes infection, then inoculum gradually die, and accordingly the level of inoculum decreased and become unable to causes infection. Contrary, when narrow host plant is continuously sown, the pathogen is able to live; complete life cycle and reproduce, thus, inoculum gradually increased, and consequently the level of inoculums will progressively increase.

Furthermore, there are some diseases, such as seedling damping off (Pythium spp.) and root rots (Rhizoctonia solani and Fusarium spp.), that can be managed only by combining the rotation, with additional methods might suggested, such as using appropriate seed treatments, delaying seeding, and installing tile drainage. On the other hand, some diseases such as Stewart's wilt and common rust of corn do not rely on overwintering in soil or crop residue and are not affected by crop rotation.

Conclude from the previous presentation that the crop rotation is one of the most important management approaches able to overcome some insect pests (Anderson, 2008). Crop sequences are most effective practice able to eliminate that 
feed on a narrow range of crops, and that laid eggs or larvae in the soil. For example rootworm in corn, wireworms, white grubs, and some cutworms is an insect that has traditionally been controlled by following crop sequence (Teetes \& Pendleton, 1999). Kaye et al. (2007), found that crop rotations also has an indirect control insect and disease cycle, through better weed control, and able to restrain and stop their progress.

\section{Rotations and weed management}

Rotation can have large impacts on weed distributions, pressure and turn off long life cycle. Rotations provide a good opportunity to rotate the use different types of herbicides and choosing chemistries which have a different mode of actions, over sequential years. Thus, overcome undesirable weeds and decreasing the ability of weed resistance. Liebman \& Dyck, (1993), registered that crop rotation (temporal change) plans can decreases weed population, tolerability and biomass production. Furthermore, adding another cropmay help further manage weeds (Cavigelli et al., 2013). A good rotation program should be productive, minimize risk of weed developing, and offer pliability against more growing weeds, e. g., annual summer weeds may not able to successfully sprout under winter crops such as wheat or they are cut before completely formation seeds in the time of wheat are harvested. In addition, grown very similar crops for two years in a row and then skipped for four or more years (e. g., corn-corn soybean- soybean-wheatwheat), allowing for the use of herbicides with long residuals in the first year of each crop while maintaining a long period (four years) where the land is rotated to other crops (Beck, 2003).

Inoculation rotations with forage crops (grass or broad-leaved forage) in long-term rotations can help to reduce weeds population and also can assists to control perennial and annual weeds as long as the forage stand is healthy and vigorous. Weed control is improved quantity and quality of forage, when harvesting forage crop as hay or silage, the seeds of weeds are not yet formed and often are not valuable component and can be ignored.

Similarly, an advantage can be gained by a rotation between warm- and cool-season crops, where each cycle is held for two seasons (two warm-season crops followed by two cool-season crops), holding the given pattern for two years disrupts weed life cycles such that the weed seeds have to survive for three years (Anderson, 2008).

Finally, can conclude that crop rotation helps to decrease the growth of weeds, which received or not received herbicides, as compared to monocropping system, thus, adopting crop rotation is a way for reducing and eliminating weeds is an acceptable method for reducing the use of pesticides and decreasing the total costs.

Rotations and soil structure and microbial communities

Several studies at different agro-ecological zone indicated that soil physiochemical parameters (properties), included infiltration, bulk density, aggregate stability, water capacity, soluble cations, anions, EC, and available nutrients as well as biological composition can improve through the use of irregular crops with taproots and fibrous roots, through the formation of humus from decomposing plant resides after harvest. Such system allows for many options when deciding on tillage practices, for example no-till or reduced tillage systems (Raimbault \& Vyn, 1991; Campbell \& Zentner, 1993; Bremer et al., 2008 and Snapp et al., 2010). A long-term field experiment evaluating different four-year rotation sequences was established, in this experiments consider combinations of small grains, legumes and oil-seed crops, results indicated that, rotation-sequence-specific benefits at both the soil and plant level in greater soil carbon accumulation, $\mathrm{C}: \mathrm{N}$ ratio improvement and soil aggregate stability (Benitez et al., 2017). When the rotation includes forages legume crops, particularly alfalfa, marginal advantage to following crops decreases after the alfalfa stand in soil is three years old.

Rotating crops also had significant effect on microbial communities. Several studies registered that, overtime, crop rotation can improve soil biological composition. It is well known that microbial societies are associated with many factors, among these host plant identity and genetics, soil characteristics and climatic conditions. Microbial species are respond to plants and are directly influenced by the root's architecture as well as the chemical characteristics of root exudates (Garbeva et al., 2004; Berg \& Smalla, 2009; Lehman et al., 2015 and Benitez et al., 2017). Early time, Johnson et al. (1992), reported that crop rotations 
enhanced mycorrhizal associations with plants establish. Additionally, in crop rotating with a high C/Nratio (corn, small grains) with low carbon to nitrogen ratio crops (soybeans) helps construct a wide-ranging population of soil micro-organisms. Such effect on soil microorganism groups along with development in soil tilth can lead to more steady soil structure and minimized the ability of soil erosion.

So, crop rotation helps receiving a good soil structure (alternatively shallow and deep rooting roots), high organic matter, good water distribution in root zone, particularly in combination with maintenance tillage, rising yield productivity.

Rotations and soil nutrient statusand
availability

Recently, the majority of literature indicates that, crop rotation is a foundational element of sustainability and long-term profitability without any needs to additional financial investments (Stanger et al., 2008 and Sexton, 2016). Additionally, appropriate crop rotation based on information of soil health is an important tool for assessing soil nutrients balance, crop nutrient requirements, and remains soil enriched or at least preventing it from running out speedily (Chuan, 2013 and Paul et al., 2014).

According to the fact that, the response to fertilizer inputs is differentiated by crop species and segregated as the soils native fertility is variances, then application of fertilizer is not always means that an increasing in crop yield must be occurred; a part of added fertilizers may be not absorbed by cropsand mostly are remained in soil in different form (available or fixed) or may be lost through volatilizing in the environment or leaching to underground water. Hence, adopting satisfactory crop rotations program can able to improve soil productivity, eliminating the constraints, sustaining food security and satisfying economic yield without or with minimum risk in environment pollution (Zingore et al., 2007, Hossain et al., 2008, Snapp et al., 2010; Zingore et al., 2011; Zhang et al., 2012 and Tittonell \& Giller, 2013).

Although, rotations has notable effects on soil nutrients content, essentially related to nitrogenfixating (Carpenter-Boggs et al., 2000), several researchers have concluded that there are others effects outside that, which can be clarified by soil mineral contents (Wright, 1990; Bullock, 1992 and Copeland \& Crookston, 1992); improved soil structure (Raimbault \& Vyn, 1991); improve nutrient use efficiency (Karlen et al., 1994 and Tanaka et al., 2005); increased soil organic matter contents,as a result of large amount of crop residue was left in the soil after harvest (Campbell \& Zentner, 1993; Bremer et al., 2008; Adiku et al., 2009; Ali et al., 2010; Zhang et al., 2012 and Sexton et al., 2014); also crop rotation can have substantial positive influence on plant nutrients uptake and mitigating the effects of limited nutrient availability of $\mathrm{N}, \mathrm{P}, \mathrm{K}$ and $\mathrm{Ca}$ for cereal crops (Bolton et al., 1976; Higgs et al., 1976; Welch, 1976; Copeland \& Crookston, 1992; Riedell et al., 1998; Brozyna et al., 2013 and Abdul Quddus et al., 2017). Marginal benefit also can be gained in managing the production of crop residues by adopting crop rotation system as compared with monoculture, when high biomass and crop residue were formed (such as corn) are recommended to sequence with crops that produce more subtle residue similar soybean.

Also, increasing the availability of most nutrients through appropriate crop rotation means fewer fertilizer uses, lower costs paid and higher farmer returns. Adding legumes to a rotation, alike soybean or alfalfa have a great possibility to increase fixer nitrogen rate (N-fixing), and then $(\mathrm{N})$ available for succeeding crops will be increased (Peterson \& Varvel, 1989 a; Raimbault \& Vyn, 1991; Carpenter-Boggs et al., 2000 and Mallarino \& Rueber, 2006). Furthermore, deeprooted legume crops, such as alfalfa, forage deep residual soil $(\mathrm{N})$ and consequently increase soil $\mathrm{N}$ availability to succeeding shallow-rooted crops (Mathers et al., 1975 and Karlen et al., 1994). Many researchers also concluded that, the influences of crop rotation on soil mineral status, particularly "nitrogen credit" for example, corn succeeding soybean is may be due to soybean roots and root exudates increasing the pool of easily mineralized organic- N (Wright, 1990; Copeland \& Crookston, 1992 and Murrell, 2011), crop rotation can also play a major role in minimizing the potential risk of nitrate leaching to soil surface and underground water by enhancing soil $(\mathrm{N})$ availability, thus the application of fertilizer $(\mathrm{N})$ will be decreased. Additionally, the rate of $(\mathrm{N})$ conversion from organic- $\mathrm{N}$ to mineral- $\mathrm{N}$ were influence by modifying soil moisture, soil temperature, $\mathrm{pH}$, plant residue, decomposing process and tillage practices (Sisti et al., 2004 and Murrell, 2011). 
Rotations and water use

Crop rotations are long-term plans, over time, rotations can improved soil structure (infiltration, bulk density, aggregate stability and water capacity), Horst \& Hardter (1994), reported that crop rotation also, can increase soil water-holding capacity as well as developing macro pores in the soil promotes new root growth in consecutive crops. Moreover, Raimbault \& Vyn (1991); stated that, improve root function and nutrient use efficiency (Copeland et al., 1993; Karlen et al., 1994 and Tanaka et al., 2005). Additionally, cropping system is more frequently with wateruse, for example cropping system has highly water-use viz.,corn, soybean and alfalfa, whereas barley, winter wheat, field peas and canola are low water-use crops. Due to, increasing the efficiency of crop rotations on water-use, crop rooting depth should be considered. Crops with deep extensive root systems that grow late into the season (e. g., sunflower and alfalfa) are likely to leave less reserve moisture than shallowerrooted, earlier maturing crops (e. g., peas, flax and lentils). Similarly, an advantage can be gained by a rotation; the large amount of residue from high vigor crops such as corn is an asset in building soil organic matter, then improving soil physical properties, which are reflected in decreasing soil water loss and protecting the soil from erosion.

Researchers conducted by many author shows that, different crops has different critical periods for water stress throughout the growing season. For example, wheat partially escapes droughtstress by flowering early and completing its cycle life earlier in the growing season than either corn or soybeans. Soybean flowering is spread over several weeks so that it can better avoid the effects of drought. Whereas, corn flowers and sets seed are at one point in time and does this during the warmest part of the season, when evaporative demand (water use) is at its peak. High temperatures and drought stress can reduce corn kernel set by decreasing pollen viability and delaying silking. Thus, seeding varieties of different time of maturities, the length of the pollination period for the farm can be expanded few weeks. Christian et al. (2012), reported that, rotation included or not included legumes canimprove water infiltration (between 70 and $238 \%$ ), soil moisture and crop productivity. Therefore, adopting a suitable rotations be able to distributing the critical water-use periods across the growing season, by this way crop rotation could mitigated the harmful effects of drought and increased water use efficiency (Roder et al., 1989; Varvel, 1994; Al-Kaisi et al., 2003 and Tanaka et al., 2005).

Rotations and crop yield potential and yield diversity

Yield gaps are poverty traps; and following crop rotations can increase soil productivity by improving soil conditions and reducing weed inhabitants and insect populations, even under conventional tillage programs. Additionally, rotations help producers use conservation tillage successfully (Roth, 1996).

In addition, rotation also have considerable positive influence on yield potential (Peterson \& Varvel, 1989 b), when compared with monoculture system and presented the greatest opportunity for increasing productivity from the current average and maximizing farmer incomes (Snapp et al., 2003; Mallarino \& Rueber, 2006; Snyde \& Bruulsema, 2007; Snapp et al., 2010; Murrell, 2011 and Yousaf, 2016). Also, notable increment was registered in grain yield of maize grown in rotation; amounted (10 to $17 \%$ ) as compared to continues sowing system (Mannering \& Griffith, 1981; Dick et al., 1986 and Higgs et al., 1990).

Adopting a good rotation can help producers escape from serious problems associated with the confliction between seeding and harvest times of different crops (i. e., trying to seed one crop when harvesting another or harvesting more than one crop at a time). Also information on market prices, which is changed with time, it is important to protect farmers from realizing potential losses. Also, crop rotations improved yield quality parameters (Kaye et al., 2007) and reduced the variability (Varvel, 2000).

\section{Rotations and allelopathy}

Allelopathy is the overpowering plant growth of a definite plant species by another plant species. In the same subject,auto toxicity occurs is a specific plant type, when chemical compounds released from root, such as corn, had a harmful effect on the same crop, if it was the succeeding. Several studies indicated that auto toxicity had conflicted effect that delaying corn seed sprouting and early season growth. While, it is not thought to be a primary cause of yield disadvantages in case of corn succeeding corn, this is may beprobably a contributing factor (Elmore \& Abendroth, 2007). 
Designing most suitable crop rotations is important to avoid any conflictions between the present crop and the following crop. Producers need to look at rotations as one tool for optimizing long-term profitability and reducing risk. Practically, achieving these goals is complicated, as one management practice may have negative implications on other practices.

Rotations and flexibility and risk management

Flexibility means adapting rotation, which can able to change, to achieve the fewer disadvantages and higher advantages. Also, adopting suitable rotation, this is highly linked to market forces and prices by regulating it slightly. If market prices are satisfactory for cereals, you may accept cereal rotation, e. g. wheat, corn, sorghum and barley. If prices for legumes are good, you can alterate to beans, and peas. If forage seed prices are good, you might extend your forage seed crop for one year. Although, adapting flexible crop rotations in depends on market and a good price, but these might be likely to change by the time from product to sell, unless we have hedged them in.

Adopting appropriate crop rotations is a complex practice; due to it is acombination of art and science. For any given state, there will be a range of rotations that are suitable. Within this range, there are rotations and tillage practices that reduce or increase risks.

\section{References}

Abdul Quddus, Md., Joinul Abedin, M. Md., Habib Mohammad, N., Ashraf Hossain, Md., Sarmin, S. and AbdusSattar, Md. (2017) Crop yields, nutrient uptake and apparent balances for lentilmungbean-T. Aman rice cropping sequence in calcareous soils. American J. Plant Biology, 2(3), 88-100.

Adiku, S.G.K., Jones, J.W., Kumaga, F.K. and Tonyigah, A. (2009) Effects of crop rotation and fallow residue management on maize growth, yield and soil carbon in a savannah-forest transition zone of Ghana. J. Agricultural Science, 147, 313-322.

Ali, A.M., Alam, M.R., Molla, M.S.H. and Islam, F. (2010) Crop productivity as affected by fertilizer management options in Boro-T. cropping pattern at farmer's fields. Bangladesh J. Agril. Res. 35(2), 287-296.
Al-Kaisi, M., Hanna, M. and Tidman, M. (2003) Crop rotation considerations for 2004 management season. In: "Integrated Crop Management". Iowa State University. http://www.ipm.iastate.edu. (Accessed August 4, 2003).

Anderson, R.L. (2008) Diversity and no-till: Keys for pest management in the U.S. Great Plains. Weed Sci. 56, 141-145.

Beck, D.L. (2003) Profitable No-Till Systems Designed for Producers in the North American Great Plains and Prairies. Conference Proceedings, 2003, $6^{\text {th }}$ Annual Northwest Direct Seed Cropping Systems Conference. Pasco, WA. (14).

Benitez, Maria-Soledad, Shannon, L.O. and Michael, L.R. (2017) Effects on maize seedling health and associated rhizosphere microbiome. Scientific Reports, 7: 15709 DOI: 10.1038/s41598-01715955-9 1. (On line 16 November2017).

Berg, G. and Smalla, K. (2009) Plant species and soil type cooperatively shape the structure and function of microbial communities in the rhizosphere. FEMS Microbiol.Ecol. 68, 1-13.

Bolton, E.F., Dirks, V.A. and Aylesworth, J.W. (1976) Some effects of alfalfa, fertilizer and lime in corn yield on rotations on clay soil during a range of seasonal moisture conditions. Can. J. Soil Sci. 56, 21-25.

Bremer, E., Janzen, H.H., Ellert, B.H. and McKenzie, R.H. (2008) Soil organiccarbon after twelve years of various crop rotations in an Aridic Boroll. Soil Sci. Soc. Am. J. 72, 970-974.

Brozyna, M.A., Petersen, S.O., Chirinda, N. and Olesen, J.E. (2013) Effect of grass-clover management and cover crops on nitrogen cycling and nitrous oxide emissions a stockless organic crop rotation. Agric. Ecosyst. Environ. 181, 115-126.

Bullock, D.G. (1992) Plant growth promoting H2oxidizing bacteria as seed inoculants for cereal crops. Crop rotation. Critical Reviews in Plant Sciences, 11, 309-326.

Campbell, C.A. and Zentner, R.P. (1993) Soil organic matter as influenced by crop rotations and fertilization. Soil Science Society of American Journal, 57, 1034-1040. 
Carpenter-Boggs, L., Reganold, J.P. and Kennedy, A.C. (2000) Effects of biodynamic preparations on compost development. Biological Agriculture and Horticulture, 17(4), 313-328.

Cavigelli, M., Teasdale, J. and Spargo, J. (2013) Increasing crop rotation diversity improves agronomic, economic and environmental performance of organic grain cropping systems at the USDA-ARS Beltsville farming systems project. (Published 29 April 2013- 4 pages).

Christian, T., Stephanie, C. and Leonard, R. (2012) Benefits and challenges of crop rotations in maizebased conservation agriculture (CA) cropping systems of southern Africa. Int. J. Agricultural Sustainability, I First article, 1-17 (Accessed10 Jul 2012).

Copeland, P.J. and Crookston, R.K. (1992) Crop sequence affects nutrient composition of corn and soybean grown under high fertility. Argon. J. 84, 503-509.

Copeland, P.J., Allmaras, R.R., Crookston, R.K. and Nelson, W.W. (1993) Corn-soybean effects on soil water depletion. Agronomy Journal, 85, 203-210.

Chuan, L.M., He, P., Pampolino, M.F., Johnston, A., Jin, J.Y. and Xu, X.P., et al. (2013) Establishing a scientific basis for fertilizer recommendations for wheat in China: Yield response and agronomic efficiency. Field Crops Res. 140, 1-8.

Dick, W.A., Van Doren, D.M., Triplett, G.N. and Henry, J.E. (1986) Influence of long-term tillage and rotation combinations on crop yields and selected soil parameters. Res. Bull. (Sun Chiwawitthaya thang Thale Phuket) Bull. 1180 Ohio Agric. Res. and Dev. Ctr., Ohio State Univ.,Wooster.

Edwards, C.A. (1995) Historical overview of vermicomposting. Biocycle, 36, 56-58.

Elmore, R. and Abendroth, L. (2007) Allelopathy: A cause for yield penalties in corn following corn. In: "Integrated Crop Management". Iowa State University. http://www.ipm.iastate.edu.Edwards, 1993.

FAO, Food and Agriculture Organization (2002) Conservation agriculture: Case studies in Latin America and Africa. FAO soils bulletin. FAO:Rome, 78.

Egypt. J. Agron. 41, No.1 (2019)
Garbeva, P., van Veen, J.A. and van Elsas, J.D. (2004) Microbial diversity in soil: Selection of microbial populations by plant and soil type and implications for disease suppressiveness. Annu.Rev. Phytopathol. 42, 243-270.

Higgs, R.L., Paulsen, W.H., Pendleton, J.W., Peterson, A.F., Jakobs, J.A. and Shrader, W.D. (1976)Crop rotations and nitrogen: Crop sequence comparisonson soil of the drift less area of southwestern Wisconsin, 1967-1974. Res. Bull. R2761. Univ. of Wisconsin College of Agric. and LifeSci., Madison, WI.

Higgs, R.L., Peterson, A.E. and Paulson, W.H. (1990) Crop rotation: Sustainableand profitable. J. Soil Water Conserve. 45, 68-70.

Horst, W.J. and Hardter, R. (1994) Rotation of maize with cowpea improves yield and nutrient compared to maize mono-cropping in an alfissol in the northern Savanna of Ghana. Plant and Soil, 160, 171-183. (Accessed: 13-09-2018 09:44).

Hossain, M.A., Jahiruddin, M., Islam, M.R. and Mian, M.H. (2008) The requirement of zinc for improvement of crop yield and mineral nutrition in the maize-mungbean-rice system. Plant Soil, 306, 13-22.

Johnson, N.C., Copeland, P.J., Crookston, R.K., and Pfleger, F.L. (1992) Mycorrhizae: Possible explanation for the yield decrease with continuous corn and soybean. Agron. J. 84, 387-390.

Karlen, D.L., Varvel, G.E., Bullock, D.G. and Cruse, R.M. (1994) Crop rotationsfor the $21^{\text {st }}$ century. $A d v$. Agron. 53, 1-44.

Karlen, D.L., Hurley, E.G., Andrews, S.S., Gambardella, C.A., Meek, D.W., Duffy, M.D., and Mallarino, A.P. (2006) Crop rotation effects on soil quality atthree northern corn/soybean belt locations. Agronomy Journal, 98, 484-495.

Kaye, N.M., Mason, S.C., Jackson, D.S. and Galusha, T.D. (2007) Crop rotationand soil amendments alters sorghum grain quality. Crop Sci. 47, 722-729.

Liebman, M. and Dyck, E. (1993) Crop rotation and intercropping strategies for weed management. Ecological Applications, 3(1), 92-122.

Lehman, R. M. et al. (2015) Understanding and enhancing soil biological health: The solution for reversing soil 
degradation. Sustainability, 7, 988-1027.

Mallarino, A. and Rueber, P. (2006) Yield of corn, soybean and oats as affected by crop rotation and nitrogen fertilization for corn. Iowa State University. http://www.agronext.iastate.edu

Mannering, J.V. and Griffith, D.R. (1981) Value of crop rotation under varioustillage systems. Agron. Guide AY-230. Coop. Ext. Serv., Purdue Univ.,West Lafayette, IN.

Mathers, A.C., Stewart, B.A. and Blair, B. (1975) Nitrate removal from soil profiles by alfalfa. $J$. Environ. Qual. 4, 403-405.

Murrell, T.S. (2011) The science behind the nitrogen credit for soybeans. International Plant Nutrition Institute. http://www.ipni.net.(Accessed December 2011) Plant Nutrition TODAY Better Crops, Better Environment through Science

Paul, F., Brentrup, F., BruuIsema, T., Garcia, F., Norton, R. and Zingore, R.S. (2014) Chapter 1. Nutrient/fertilizer use efficiency: Measurement, current situation and trends. IFA, IWMI, IPNI and IPI. April 2014. 30 P. [Accessed Dec 19 2018].

Pedersen, P. and Lauer, J.G. (2004) Soybean growth and development response to rotation sequence and tillage system. Agronomy Journal, 96, 1005-1012.

Peterson, T.A. and Varvel, G.E. (1989 a) Crop yield as affected by rotation andnitrogen rate. I. Soybean. Agronomy Journal, 81, 727-731.

Peterson, T.A. and Varvel, G.E. (1989b) Crop yield as affected by rotation andnitrogen rate. II. Sorghum. Agronomy Journal, 81, 731-734.

Raimbault, B.A. and Vyn, T.J. (1991) Crop rotation and tillage effects on corngrowth and soil structural stability. Agronomy Journal, 83, 979-985.

Riedell, W.E., Schumacher, T.E., Clay, S.A., Ellsbury, M.M., Pravecek, M. and Evenson, P.D. (1998) Corn and soil fertility responses to crop rotationwith low, medium, or high inputs. Crop Sci. 38, 427-433.

Roth, G. (1996) Crop rotations and conservation tillage. Penn State Extension. The Pennsylvania State University, 201 Willard Building, University Park, PA 16802-2801: http://extension.psu.edu.
Sisti, C.P.J., et al., (2004) Change in carbon and nitrogen stocks in soil under 13 years of conventional or zero tillage in southern Brazil. Soil and Tillage Research, 76, 39-58.

Seeley, M.W.( 2012) Climate trends and issues in the North-Central region. Carbon, Energy and Climate Conference Proceedings. USDA-SARE and Michigan State University, Kellogg Biological Station.Hickory Corner, MI.

Sexton, P. (2016) Chapter 9: Crop rotations can increase corn profitability and reduce pests. In: "iGrow Corn: Best Management Practices", Clay, D.E., C.G. Carlson, S.A. Clay and E. Byamukama (Ed.). South Dakota State University. 9.19.7.www. iGrow.org.

Sexton, P., Berg, R. and Beck, D. (2012) Effect of cover crops on corn $\mathrm{N}$ requirements in a drought year. South Dakota State University Agricultural Experiment Station. Southeast Research Farm Annual Progress Report, pp. 21-25.

Sexton, P., Johnson, D. and Rops, B. (2014) Evaluation of effects of cover crops on corn $\mathrm{N}$ requirements 2014. South Dakota State University Agricultural Experiment Station. Southeast Research Farm Annual Progress Report, pp. 30-32.

Snapp, S.S., Blackie, M.J. and Donovan, C. (2003) Realigning research and extension services: Experiences from southern Africa. Food Policy, 28, 349-363.

Snapp, S.S., et al., (2010) Biodiversity can support a greener revolution in Africa. Proceedings of the National Academy of Sciences of the United States of America, 107, 20840-20845.

Snyder, C.S. and Bruulsema, T.W. (2007) Nutrient use efficiency and effectiveness in North America. In: "Indices of Agronomic and Environmental Benefit", Int. Plant Nutr. Inst. Publ.

Stanger, T.F., Lauer, J.G. and Chavas, J.P. (2008) The profitability and risk of long-term cropping systems featuring different rotations and nitrogen rates. Agron. J. 100, 105-113.

Tanaka, D.L., Anderson, R.L. and Rao, S.C. (2005) Crop sequencing to improveuse of precipitation and synergize crop growth. Agronomy Journal, 97, 385-390. 
Teetes, G. and Pendleton, B.B. (1999) "Insect Pests of Sorghum: Cultural Management Methods". Department of Entomology. Texas A\&M University. http://sorghumipm.tamu.edu. (verified 9/3/14).

Tittonell, P. and Giller, K.E. (2013) when yield gaps are poverty traps: the paradigm of ecological intensification in African smallholder agriculture. Field Crops Res. 143, 76-90.

Varvel, G.E. (1994) Monoculture and rotation system effects on precipitation use efficiency of corn. Agronomy Journal, 86, 204-208.

Varvel, G.E. (2000) Crop rotation and nitrogen effects on normalized grain yields in a long-term study. Agronomy Journal, 92, 938-941.

Walter Riedell, E., Joseph, L., Jr. Pikul, A., Jaradat Abdullah and Thomas, E.S. (2009) Crop rotation and nitrogen input effects on soil fertility, maize mineral nutrition, yield, and seed composition. Agronomy Journal, 101(4), 870-879.

Wright, A.T. (1990) Yield effect of pulses on subsequent cereal crops in the northern plains. Can. J. Plant Sci. 70, 1023-1032.

Welch, L.F. (1976) Th e Morrow Plots: Hundred years of research. Ann. Agron. 27, 881-890.
Yousaf, M. et al. (2016) Nitrogen fertilizer management for enhancing crop productivity and nitrogen use efficiency in a rice-oilseed rape rotation system in China. Front Plant Sci. 7.

Zingore, S., Murwira, H.K., Delve, R.J. and Giller, K.E. (2007) Soil type, management history and current resource allocation: Three dimensions regulating variability in crop productivity on African smallholder farms. Field Crops Res. 101, 296-305.

Zingore, S., Tittonell, P., Corbeels, M., Van Wijk, M.T. and Giller, K.E. (2011) Managing soil fertility diversity to enhance resource use efficiencies in smallholder farming systems: A case from Murewa District, Zimbabwe. Nutr. Cycl. Agroecosyst, 90, 87-103.

Zhang, F., Cui, Z., Chen, X., Ju, X., Shen, J., Chen, Q., Liu, X., Zhang,W., Mi, G., Fan, M., Jiang, R., 2012. Integrated nutrient management for food security and environmental quality in China. Adv. Agron. 116, 1-40-

(Received 11/12/2018; accepted 13/1/2019)

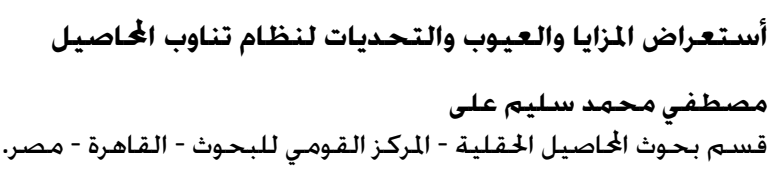

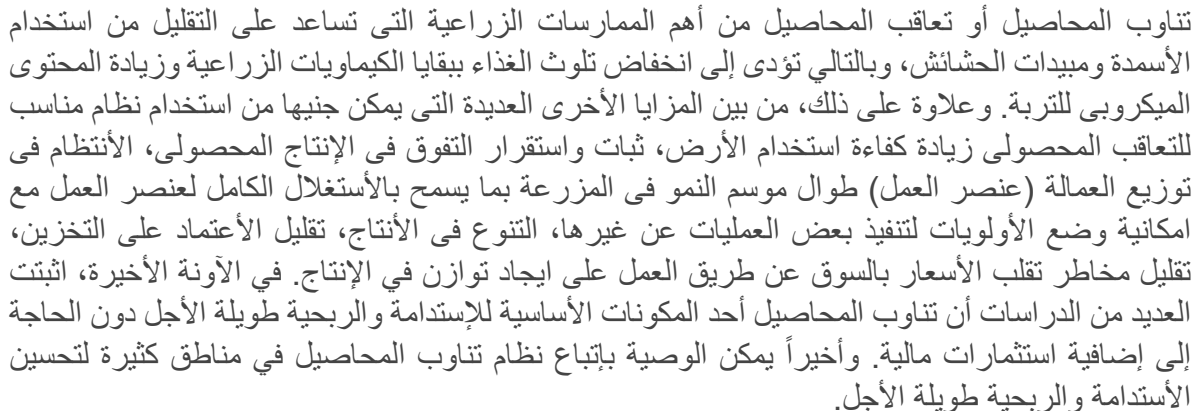

Egypt. J. Agron. 41, No.1 (2019) 